\title{
Combining ability studies for yield and contributing traits in okra (Abelmoschus esculentus L. Moench)
}

\author{
Arti Verma*, Sonia Sood and Yudhvir Singh \\ 176062 (H.P.), INDIA \\ *Corresponding author. E-mail: verma.arti104@gmail.com \\ Received: February 08, 2016; Revised received: May 30, 2016; Accepted: August 18, 2016
}

Department of Vegetable Science and Floriculture, CSK Himachal Pradesh Agricultural University, Palampur-

\begin{abstract}
The present investigation was carried out to identify desirable parents and $F_{1}$ hybrids in okra by involving eight diverse parents in a diallel mating design excluding reciprocals. Genotypes i.e., P-20 and VRO-4 for earliness; 9801 for first fruit producing node $(-0.085)$, internodal length $(-0.659)$ and fruit length $(0.201)$; HU for average fruit weight (0.603); Tulsi-I for nodes per plant (0.429), fruit length (0.271) and plant height (12.068) were found good general combiners appeared to be worthy of exploitation in future breeding. It is suggested that involving these lines, new genotypes may be developed through multiple crossing for isolating high yielding varieties. The cross combinations VRO-4 $\times$ HU, Tulsi-I $\times$ SKBS-11, P-20 $\times$ Tulsi-I and P-8 $\times$ Tulsi-I showed high SCA effects as well as per se performance for yield per plant. The crosses showing high SCA effects and per se performance for yield per plant suggested that these hybrids may be exploited in further breeding programme.
\end{abstract}

Keywords: Abelmoschus esculentus, Combining ability, Diallel analysis, Okra

\section{INTRODUCTION}

Okra (Abelmoschus esculentus (L.) Moench) is an important fruit vegetable crop of the tropical, sub-tropical and warmer parts of temperate regions of the world. The crop shows preference for the tropical and sub-tropical climates, and it is of tremendous significance as a vegetable in these areas (Oyetunde and Ariyo, 2014). It belongs to Malvaceae family and grown in kharif and zaid seasons. It is thought to have been originated in India (Zeven and Zukovasky, 1975). Its tender green fruits are used as vegetable and mature fruits, roots and stems are used in paper industry and clearing gur or raw sugar. Green fruits are rich in vitamins $(\mathrm{C}, \mathrm{A}$ and $\mathrm{B})$ and minerals $(\mathrm{Ca}, \mathrm{P}, \mathrm{Mg}$ and $\mathrm{Fe})$. It is an interesting crop to the breeders and geneticists for its monoadelphous condition of the stamens and large flower amendable to easy emasculation and fruit bears large number of seeds. There is a need to increase overall production to meet the inflating demand. This can be accomplished either by increase in area under cultivation or raising the productivity. The increase in productivity can be achieved by adopting the high yielding $\mathrm{F}_{1}$ hybrids. The success of a breeding programme depends upon the choice of suitable parents and their utilization by adopting an appropriate breeding method. The combining ability analysis has been extensively used to identify potential parents either to be used in the development of hybrids or recombinant breeding for getting elite purelines.

Among several techniques, diallel cross analysis is one of the most powerful tool for characterizing the genetic architecture of plant genotypes and estimating the GCA of parents and selecting desirable parents and crosses with high SCA for the exploitation of heterosis (Reddy et al., 2012; Ali et al., 2013). Developing improved varieties with high yield potential is continuous process and for hybridization, the choice of parents is based on information on combining ability of parents. The concept of general combining ability (GCA) and specific combining ability (SCA) was given by Sprague and Tatum (1942). They further reported that GCA is dependent mainly on additive gene effects and additive $\times$ additive type of epistasis, whereas SCA includes both dominance and epistasis. According to them, the GCA is the average performance of line in a series of hybrid combinations, and the SCA refers to those cases in which certain combinations do relatively better or worse than would be expected on the basis of the average performance of the lines involved. Griffing (1956) defined techniques for estimating the GCA and SCA effects under different situations. Keeping this in view, the experiment was designed to have information on general and specific combining ability estimated in okra through diallel mating.

\section{MATERIALS AND METHODS}

The material for the investigation comprised eight okra genotypes viz., P-20, 9801, VRO-4, Parbhani Kranti (PK), P-8, Hisar Unnat (HU), Tulsi-I and SKBS-11 (Table 1) which were maintained through selfing during 2011 and crossed in diallel mating design (excluding reciprocals) during 2012 to generate $28 \mathrm{~F}_{1}$ hybrids. All the $\mathrm{F}_{1}$ 's along with their parents and hybrid Tulsi, a standard check were evaluated in a Randomized Block Design with three replications during 
summer-rainy season of 2013 at Experimental Farm of the Department of Vegetable Science and Floriculture, CSKHPKV, Palampur. The field is located at $32^{\circ} 6^{\prime} \mathrm{N}$ latitude, $76^{\circ} 3^{\prime} \mathrm{E}$ longitude and $1290.8 \mathrm{~m}$ altitude. The crop was raised in three rows of $2.5 \mathrm{~m}$ length with inter and intra row spacing of $45 \mathrm{~cm}$ and $15 \mathrm{~cm}$, respectively. The observations were recorded on five competitive plants in each entry and replication for the parameters viz., days to $50 \%$ flowering, days to first picking, first fruit producing node, nodes per plant, internodal length $(\mathrm{cm})$, average fruit weight $(\mathrm{g})$, plant height $(\mathrm{cm})$, harvest duration (days), fruits per plant and fruit yield per plant $(\mathrm{g})$. For the parameters viz., fruit length $(\mathrm{cm})$ and fruit diameter $(\mathrm{cm})$, a random sample of five fruits/entry/ replication was drawn from fourth and eighth pickings. The combining ability analysis was computed by method II (parents plus one set of crosses but no reciprocals), Model I (fixed effect Model) as described by Griffing (1956).

\section{RESULTS AND DISCUSSION}

Analysis of variance for combining ability for quantitative traits in okra: The analysis of variance for combining ability effects was carried out for all the twelve attributes in $\mathrm{F}_{1}$ generation and the results are presented in Table 2 . The mean square due to general combining ability (GCA) were found significant $(\mathrm{P} \leq 0.05)$ for all the traits, except for fruits per plant and fruit yield per plant, while mean square due to specific combining ability (SCA) were significant for most of the traits with few exceptions, viz., average fruit weight and harvest duration. The significant results indicated the presence of additive and non-additive gene action in the inheritance of various traits. Involvement of both additive and non-additive components of heritable variance was also reported by Reddy et al., (2012) for number of branches per plant, internodal length, days to $50 \%$ flowering, first flowering node, first fruiting node, fruit length, fruit width, fruit weight, total number of fruits per plant, number of marketable fruits per plant, total yield per plant, marketable yield per plant and YVMV infestation on fruits and Bhatt et al., (2015) for days to first flowering, days to first picking, plant height, number of nodes per plant, length of internode, number of primary branches per plant, stem girth, fruit girth, fruit weight, number of fruits per plant and fruit yield per plant.

Estimates of combining ability effects for quantitative traits in okra: General combining ability (GCA) studies have successfully led to making choice of suitable parents (Table 3). All the parents exhibited variable results for combining ability as no single parent exhibited significant $(\mathrm{P} \leq$ 0.05) GCA effects for all the traits. Genotype VRO-4 showed the highest GCA effects for days to $50 \%$ flowering, days to first picking, internodal length and harvest duration. It was observed that the parents P-20 for days to $50 \%$ flowering and fruit diameter; P-8 for first fruit producing node; HU for average fruit weight and Tulsi-I for nodes per plant, fruit length and plant height showed the highest general combining ability effects. The parent 9801 was good general combiner for first fruit producing node, internodal length and fruit length. Sig-

Table 1. Sources and characteristics of eight parental lines of okra (A. esculentus ) used in half-diallel at Palampur, India.

\begin{tabular}{cllll}
\hline S. No. & Parents & Fruit colour & Plant height & Source \\
\hline 1. & P-20 & Dark green & Tall & CSKHPKV, Palampur, India \\
2. & 9801 & Dark green & Dwarf & CSKHPKV, Palampur, India \\
3. & VRO-4 & Green & Dwarf & IIVR, Varanasi, India \\
4. & Parbhani Kranti (PK) & Dark green & Tall & MAU, Parbhani, India \\
5. & P-8 & Green & Tall & PAU, Ludhiana, India \\
6. & Hisar Unnat (HU) & Dark green & Medium tall & CCS HAU, Hisar, India \\
7. & Tulsi-I & Green & Tall & CSKHPKV, Palampur, India \\
8. & SKBS-11 & Green & Tall & SKUAST, Srinagar, India \\
\hline
\end{tabular}

Table 2. Analysis of variance for combining ability for quantitative traits in okra.

\begin{tabular}{|c|c|c|c|c|c|}
\hline \multirow[b]{2}{*}{ S. No. } & \multirow[b]{2}{*}{ Traits } & \multicolumn{3}{|c|}{ Mean sum of square } & \multirow[b]{2}{*}{ Error } \\
\hline & & Source & GCA & SCA & \\
\hline & & df & 7 & 28 & 70 \\
\hline 1. & Days to $50 \%$ flowering & & $6.825^{*}$ & $2.732 *$ & 0.892 \\
\hline 2. & Days to first picking & & $9.474 *$ & $2.848^{*}$ & 1.313 \\
\hline 3. & First fruit producing node & & $0.278^{*}$ & $0.040^{*}$ & 0.021 \\
\hline 4. & Nodes per plant & & $0.873 *$ & $1.011^{*}$ & 0.341 \\
\hline 5. & Internodal length (cm) & & $3.499 *$ & $0.761 *$ & 0.115 \\
\hline 6. & Fruit length $(\mathrm{cm})$ & & $0.512 *$ & $0.266^{*}$ & 0.110 \\
\hline 7. & Fruit diameter $(\mathrm{cm})$ & & $2.655^{*}$ & $0.883^{*}$ & 0.300 \\
\hline 8. & Average fruit weight (g) & & $1.453^{*}$ & 0.522 & 0.356 \\
\hline 9. & Plant height $(\mathrm{cm})$ & & $744.936^{*}$ & $281.754 *$ & 62.676 \\
\hline 10. & Harvest duration (days) & & $14.422 *$ & 3.889 & 3.153 \\
\hline 11. & Fruits per plant & & 0.633 & $1.692 *$ & 0.386 \\
\hline 12. & Fruit yield per plant $(\mathrm{g})$ & & 124.085 & $686.900 *$ & 178.912 \\
\hline
\end{tabular}

\footnotetext{
*Significant at $5 \%$ level
} 
nificant GCA effects for days to first flowering, internodal length, number of fruiting nodes and fruit length in okra were reported by Reddy et al., (2012), Kumar et al., (2014) and Bhatt et al., (2015).

Additive parental effects, as measured by GCA effects are of great practical use to the breeders whereas nonallelic interactions are impracticable and cannot be manipulated. On the basis of present study, it can be recommended to include the parents P-20, 9801, VRO4 and $\mathrm{HU}$ for all the possible matings for selecting desirable transgressive segregants. An overall study of GCA revealed that none of parent was good combiner for all characters under investigation (Singh et al., 2012; Kumar et al., 2014 and Bhatt et al., 2015), which is due to the different genetic make up of the parents included in the study.

Specific combining ability effects represent dominance and epistatic component of variation which are nonfixable and hence, SCA studies would not contribute to the improvement in self-pollinated crops except in cases where commercial exploitation of heterosis is feasible. However, in the production of homozygous lines breeder's interest usually rests upon transgressive segregation shown in the crosses. The specific combining ability effects of crosses are presented in Table 4. It was observed that no single cross could reveal significant $(\mathrm{P} \leq$ $0.05)$ SCA for all the traits. In the present study, out of twenty eight cross-combinations P-20 $\times$ PK (good $\times$ average) for days to $50 \%$ flowering; VRO $-4 \times \mathrm{HU}(\operatorname{good} \times$ average) for days to first picking; P-20 $\times$ SKBS-11 (good $\times$ poor) for first fruit producing node; VRO $-4 \times \mathrm{HU}$ (average $\times$ poor) for nodes per plant; P-20 $\times$ SKBS-11 (average $\times$ poor) for internodal length; P-20 $\times$ P-8 (average $\times$ average) for fruit length; P-8 $\times$ Tulsi-I (average $\times$ good) for fruit diameter; HU $\times$ Tulsi-I (good $\times$ average) for average fruit weight; VRO $-4 \times \mathrm{HU}($ poor $\times$ average) for plant height; VRO- $4 \times \mathrm{HU}$ (good $\times$ average) for harvest duration; VRO- $4 \times \mathrm{HU}$ (average $\times$ average) for fruits per plant and fruit yield per plant displayed highest significant specific combining ability effects.

Majority of the cross-combinations exhibiting desirable SCA effects, had atleast one of the parent as good or average general combiner. Similar views had also been shared by Kumar et al., (2005) and Singh et al., (2012). The present findings reveal that it is not necessary that parents having higher estimates of GCA effects would also give higher estimates of SCA effects. Sometimes specific interaction effects (most likely complimentary) in poor $\times$ poor crosses may perform better than good $\times$ good, good $\times$ poor and average $\times$ poor combinations because of the prevalence of high magnitude of non-additive component for the superiority of pertinent cross-combinations. In case of crosscombination, HU $\times$ SKBS-11 (internodal length) although the significant SCA effect was observed but, this hybrid had both the parents as poor general combiners. This observation corroborate the observations of Kumar and Pathania, (2011) and Singh et al., (2012) who reported in okra that the supe- 


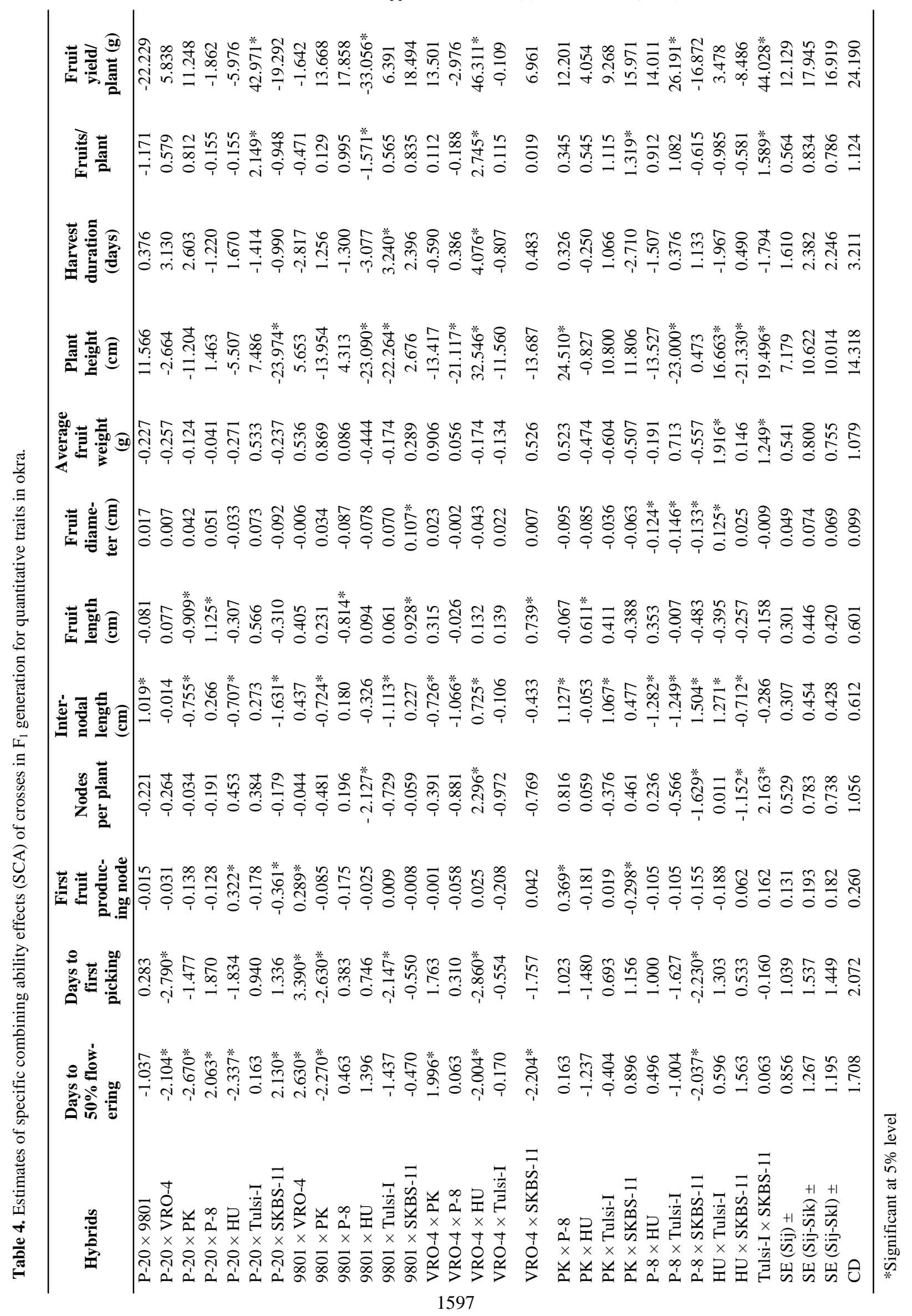


Table 5. Specific cross-combinations with high desirable SCA effects for fruit yield and related traits in okra.

\begin{tabular}{lll}
\hline Cross-combinations & $\begin{array}{l}\text { Per } \text { se performance } \\
\text { (Fruit yield/plant) }\end{array}$ & Traits with high SCA effects \\
\hline VRO-4 $\times$ HU & $270.93 \mathrm{~g}$ & $\begin{array}{l}\text { Fruit yield per plant, days to 50\% flowering, days to first pick- } \\
\text { ing, nodes per plant, plant height, harvest duration and fruits per } \\
\text { plant }\end{array}$ \\
Tulsi-I $\times$ SKBS-11 & $256.87 \mathrm{~g}$ & $\begin{array}{l}\text { Fruit yield per plant, nodes per plant, average fruit weight, plant } \\
\text { height and fruits per plant }\end{array}$ \\
$\mathrm{P}-20 \times$ Tulsi-I & $255.93 \mathrm{~g}$ & Fruit yield per plant and fruits per plant \\
$\mathrm{P}-8 \times$ Tulsi-I & $232.87 \mathrm{~g}$ & Fruit yield per plant, internodal length and fruit diameter \\
\hline
\end{tabular}

rior hybrids need not necessarily have parents showing high GCA effects.

The combinations exhibiting high SCA effects derived from good or average general combiners will be of main interest as they certainly perform better for a particular trait. The cross-combination P-20 × VRO-4 can be exploited to isolate transgressive segregants in early generations as they involve both parents with high GCA effects for early harvest. Similarly, cross combinations $(\mathrm{P}-20 \times \mathrm{PK}, \mathrm{P}-20 \times \mathrm{HU}, \mathrm{VRO}-4 \times$ SKBS-11 and VRO-4 $\times$ HU) may give transgressive segregants in the later generations if the additive effect of one parent and complimentary epistatic effects (if present in the cross) act in the same direction and maximize the desirable plant character. Specific crosscombinations with high desirable SCA effects for fruit yield and related traits are presented in Table 5. The high significant positive SCA effects for fruit yield per plant were recorded in VRO- $4 \times$ HU followed by Tulsi -I $\times$ SKBS-11, P-20 $\times$ Tulsi-I and P-8 $\times$ Tulsi-I. Breeding for homozygous lines by conventional pedigree and back cross method could be use only partial exploitation of additive genetic variance. In order to exploit different types of gene actions in a population it is suggested that a breeding procedure which may accumulate the fixable type of gene effects and at the same time maintains considerable heterozygosity for exploitation dominance gene effects might prove most beneficial to improve the population of okra.

\section{Conclusion}

From the data presented in this study, it could be concluded that both additive and non-additive gene actions played the major role in the inheritance of various traits. P-20, 9801, VRO-4 and HU showed good general combining ability for most of the traits appear to be worthy for exploitation of segregation and varietal development. Cross combinations VRO-4 $\times$ HU, Tulsi -I $\times$ SKBS-11, P-20 $\times$ Tulsi-I and P-8 $\times$ Tulsi-I showed high SCA effects as well as per se performance for fruit yield per plant. Therefore, it would be worthwhile to use these crosses for improvement in fruit yield per plant.

\section{REFERENCES}

Ali, H.A.O., Eldekashy, M.H.Z., Helaly, A.A. (2013). Combining ability and heterosis studies for yield and its components in some cultivars of okra (Abelmoschus esculentus L. Moench). American-Eurasian J. Agric. \& Environ. Sci. 13: 162-167.

Bhatt, J.P., Kathiria, K.B., Christian, S.S., Acharya, R.R. (2015). Combining ability studies in okra (Abelmoschus esculentus (L.) Moench) for yield and its component characters. Electronic J. Plant Breed. 6: 479-485.

Griffing, J.B. (1956). Concept of general and specific combining ability in relation to diallel crossing system. Australian J. Biol. Sci. 9: 463-493.

Kumar, R., Yadav, J.R., Tripathi, P., Tiwari, S.K. (2005). Evaluating genotypes for combining ability through diallel analysis in okra. Indian J. Hort. 62: 88-90.

Kumar, S., Pathania, N.K. (2011). Combining ability and gene action studies in okra (Abelmoschus esculentus (L.) Moench). J. Research, Punjab Agricultural Uni. 48: 43-47.

Kumar, S., Singh, A.K., Das, R., Datta, S., Arya, K. (2014). Combining ability and its relationship with gene action in okra (Abelmoschus esculentus (L.) Moench). J. of Crop and Weed 10: 82-92.

Oyetunde, O.A., Ariyo, O.J. (2014). Genetics of seed yield and related traits in biparental crosses of okra, Abelmoschus esculentus (L.) Moench. Nigerian J. Genet. 28: 8-14.

Reddy, M.T., Haribabu, K., Ganesh, M., Reddy, K.C., Begum, H., Reddy, R.S.K., Babu, J.D. (2012). Genetic analysis for yield and its components in okra (Abelmoschus esculentus (L.) Moench). Songklanakarin J. Sci. Technol. 34: 133-141.

Singh, B., Kumar, M., Naresh, R.K. (2012). Combining ability analysis of yield and its components in okra. Indian $J$. Hort. 69: 195-199.

Sprague, G.F. and Tatum, L.A. (1942). General versus specific combining ability in single crosses of corn. J. American Society of Agron. 34: 923-932.

Zeven, A.C. and Zukovasky, P.M. (1975). Dictionary of Cultivated Plants and their Centers of Diversity. Centre of Agricultural Publishing and Documentation, Wegeningen, the Netherlands. 